\title{
Supercritical Carbon Dioxide Effect on Lipase-Catalyzed Geranyl Acetate Synthesis
}

\author{
Matheus V. L. Tavares, ${ }^{a}$ Luís R. S. Kanda, ${ }^{\circledR b, c}$ Wanderson R. Giacomin Júnior, ${ }^{b, c}$ \\ Luiz P. Ramos, ${ }^{c}$ Luciana P. S. Vandenberghe ${ }^{a}$ and Marcos L. Corazza ${ }^{\circledR, b, c}$ \\ a Programa de Pós-Graduação em Engenharia de Bioprocessos e Biotecnologia, \\ Departamento de Engenharia de Bioprocessos e Biotecnologia, \\ Universidade Federal do Paraná (UFPR), 81530-980 Curitiba-PR, Brazil \\ ${ }^{b}$ Laboratório de Cinética e Termodinâmica Aplicada (LACTA), \\ Departamento de Engenharia Química, Universidade Federal do Paraná (UFPR), \\ 81531-980 Curitiba-PR, Brazil \\ 'Programa de Pós-Graduação em Engenharia Química, Universidade Federal do Paraná (UFPR), \\ 81531-980 Curitiba-PR, Brazil
}

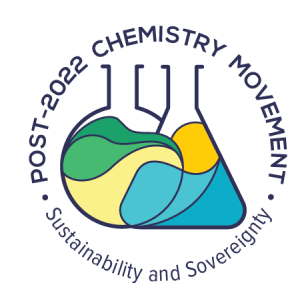

\section{Introduction}

Geraniol (trans-3,7-dimethylocta-2,6-dien-1-ol) is an acyclic monoterpene alcohol with rose-like aroma, and is the main component of essential oils extracted from palmarosa (Cymbopogon martini), citronella (Cymbopogon winterianus), and roses (Rosa $\times$ damascena and Rosa centifolia). ${ }^{1}$ This chemical is of great importance for food, flavor, fragrance, cosmetic and pharmaceutical applications. ${ }^{2}$ However, it presents a certain degree of toxicity, and the use of geranyl esters such as geranyl acetate is preferred, since they are less toxic and still retain the organoleptic properties of geraniol. ${ }^{3,4}$

Geranyl esters can be obtained by esterification, transesterification or interesterification of geraniol with different combinations of acyl donors, catalysts, and

*e-mail: corazza@ufpr.br

Editor handled this article: Teodoro S. Kaufman organic solvents which implies different types of reaction schemes with specificities of their own. ${ }^{5-17}$ Acetate esters (e.g., acetyl acetate, ${ }^{18}$ propyl acetate, ${ }^{7}$ and vinyl acetate, $, 410,19$ among others) are frequently used as acyl donors instead of acetic acid due to the possibility of the latter to act as a lipase inactivation agent. Nonetheless, if the proper reaction conditions are employed, the use of acetic acid allows the achievement of reasonably high reaction conversions. ${ }^{6,12,20}$ Biocatalysts present advantages of being versatile, more environmentally friendly, and highly specific due to chemo-, enantio-, and regio-selectivity. ${ }^{21-24}$ Moreover, commercial immobilized lipases are used instead of free enzymes, because the latter form requires more complex downstream operations in industrial processes and presents lower activity and lower stability in non-aqueous media. ${ }^{10,14,25}$

Organic solvents were employed at first to enhance transport properties but, since they are quite harmful to both the environment and human health, there has been 
a growing interest for their replacement by supercritical fluids. ${ }^{18,26-29}$ The use of supercritical fluids is particularly interesting because they can be readily separated from the reaction media by depressurization, resulting in both easier and simpler industrial downstream operations. ${ }^{30,31}$ In this sense, supercritical $\mathrm{CO}_{2}\left(\mathrm{scCO}_{2}\right)$ was employed in combination with Novozym ${ }^{\circledR} 435$ for the synthesis of ethyl palmitate, ${ }^{32}$ and isoamyl acetate. ${ }^{33,34}$ Supercritical ethane (scEthane) was also employed and, in fact, provided higher conversions for the synthesis of geranyl acetate as compared to $\mathrm{scCO}_{2}$, as demonstrated by Peres et al. ${ }^{27}$ (98 and 73\%, respectively) and Couto et al. ${ }^{26}$ (96 and 86\%, respectively).

However, $\mathrm{scCO}_{2}$ presents several advantages over scEthane, such as low toxicity, non-flammability, abundance and low-cost. ${ }^{24,31,35}$ Furthermore, it is possible to adjust both physicochemical and thermodynamic properties of $\mathrm{CO}_{2}$, by choosing the proper process conditions, especially temperature and pressure. Hence, $\mathrm{CO}_{2}$ may present both gas-like transport properties and liquid-like densities, while density-dependent properties such as relative permittivity (or dielectric constant), and solubility parameter, as well as the partition coefficient, also suffer important changes..$^{30,31,36-38}$

Table S1 (Supplementary Information (SI) section) presents a summary of studies on the synthesis of geraniol esters already available in literature..$^{3-6,8-16,19,24,26-28,36,39-46} \mathrm{~A}$ special attention must be drawn to geranyl acetate synthesis with biocatalysts and under the presence of $\mathrm{scCO}_{2}$, which is the focus of the present work. Bourkaib et al. ${ }^{24}$ performed reactions using Lipozyme ${ }^{\circledR} 435$ in a packed bed reactor (PBR) and obtained a conversion of $98 \%$. Couto et al. ${ }^{26}$ employed Novozym ${ }^{\circledR} 435$ in a stirred tank reactor (STR) and reached a molar conversion of $73 \%$. However, when the reactions were performed in a PBR, the molar conversion was around $86 \%$ after a total reaction time of 8 h. ${ }^{26}$ Peres et al. ${ }^{27}$ employed Novozym ${ }^{\circledR} 435$ in a variable volume reactor (VVR), and obtained a $73 \%$ conversion after $10 \mathrm{~h}$. Chulalaksananukul et al., ${ }^{36}$ however, achieved only $30 \%$ conversion after $72 \mathrm{~h}$ utilizing Lipozyme ${ }^{\circledR}$ as biocatalyst.

In spite of these works, there is still a lack of comprehension as to the influence of $\mathrm{CO}_{2}$, from its amount in the reaction media to its properties, which change according to temperature and pressure. Thus, the main objective of this work is to provide experimental observations for a better understanding of the role of $\mathrm{scCO}_{2}$ in the lipase-catalyzed esterification of geraniol with acetic acid as the acyl donor. First, the effects of temperature (from 40 to $\left.70{ }^{\circ} \mathrm{C}\right)$ and geraniol to acetic acid molar ratios $(1: 1$, 1.25:1, and 1.5:1) were assessed in an STR using hexane and Lipozyme ${ }^{\circledR}$ RM IM. Further, Lipozyme ${ }^{\circledR}$ RM IM was replaced by Novozym ${ }^{\circledR} 435$, hexane by $\mathrm{scCO}_{2}$ and the reactions were performed using a VVR.

\section{Experimental}

\section{Chemicals}

Lipozyme ${ }^{\circledR}$ RM IM, a commercial lipase from Mucor miehei immobilized on macroporous ion-exchange resin, was purchased from Sigma-Aldrich (São Paulo, Brazil), while Novozym ${ }^{\circledR} 435$, a commercial lipase from Candida antarctica immobilized on acrylic resin, was kindly donated by Novozymes Latin America (Araucaria, Brazil). Geraniol (99.3\%), geranyl acetate (99.2\%) and methyl laurate $(99.0 \%)$ were obtained from Sigma-Aldrich (São Paulo, Brazil). Acetic acid (99.8\%), hexane (99.0\%), and ethanol $(99.8 \%)$ were supplied by Neon (Suzano, Brazil). Phenolphthalein and sodium hydroxide (97\%) were purchased from Vetec (Duque de Caxias, Brazil) and potassium hydrogen phthalate $(99.5 \%)$ was supplied by Dinamica (Indaiatuba, Brazil). Carbon dioxide (99.9\%) was purchased from White Martins (Araucaria, Brazil). All chemicals were used as received without further purification.

\section{Stirred tank reactor (STR)}

The STR consisted of a $50.0 \mathrm{~mL}$ closed vessel mini bench-top Parr $^{\circledR}$ (Moline, USA) reactor, model 4561, equipped with a 4848 Parr $^{\circledR}$ reactor controller. The reaction medium corresponded to approximately $70 \%$ of its total volume capacity and the agitation was set to $600 \mathrm{rpm}$ in the reactor controller. The temperature was set and controlled by the reactor controller at three different values: 40,55 , and $70{ }^{\circ} \mathrm{C}$. Reaction conditions and parameters were based in previous works available in literature (cited in Table S1). Esterification was carried out in the STR system for up to 480 min with Lipozyme ${ }^{\circledR}$ RM IM and up to 240 min for Novozym ${ }^{\circledR} 435$.

The reaction mixture was prepared gravimetrically using an analytical balance, model AS220/C/2 (RADWAG, Radom, Poland), with a \pm 0.0001 g uncertainty. Geraniol to acetic acid molar ratios ranged from 1.0:1.0 to $1.5: 1.0$ and enzyme concentrations were set at 10 or $20 \mathrm{wt} \%$ in relation to the reactants' quantity. In reactions performed with hexane, the reactants were added to the reaction vessel according to the following order: alcohol, organic acid, organic solvent, and enzyme. On the other hand, when $\mathrm{scCO}_{2}$ was employed, the order was changed to: alcohol, organic acid and enzyme. Then, the reactor was closed, and an appropriate amount of $\mathrm{CO}_{2}$ was fed to the system with the help of a 260 D syringe pump (Teledyne ISCO, Lincoln, USA), whose uncertainty was $16.63 \mathrm{~nL}$. The actual amounts of each reactant, biocatalyst and solvent are presented in Tables S2 and S4 (SI section). 
Variable volume reactor (VVR)

General information about the variable volume reactor (VVR) used in this work has been already reported elsewhere. ${ }^{31,47-49}$ The experimental apparatus consisted of a high-pressure variable volume view cell containing a movable piston, which allows pressure control inside the cell. The apparatus also included a syringe pump for injecting $\mathrm{CO}_{2}$ into the cell and for manipulating pressure in the equilibrium unit, an electrical heating jacket for the temperature control, an LD301 pressure transducer (Smar, Sertãozinho, Brazil), with uncertainty of $\pm 0.03 \mathrm{MPa}$, an N1500 universal indicator (Novus, Canoas, Brazil) for pressure data acquisition, and a J-type thermocouple (Ecil, Piedade, Brazil) to measure and register the temperature inside the cell. The visual observations were achieved through two sapphire windows, one on the side and another frontal to the cell.

The experimental procedure was based on the studies of Veiga et al..$^{31}$ and Giacomin Junior et al. ${ }^{48}$ First, $\mathrm{CO}_{2}$ was flushed (at $288.15 \mathrm{~K}$ and $6.0 \mathrm{MPa}$ ) to remove any residual air, and suitable amounts of reactants and enzyme, weighed using an analytical balance, were added to the cell following the same order as used for reactions performed in the STR. Agitation around $600 \mathrm{rpm}$ was provided by a C-MAG HS4 magnetic stirrer (IKA ${ }^{\circledR}$, Staufen, Germany). Next, using a syringe pump, the proper amount of $\mathrm{CO}_{2}$ (288.15 $\mathrm{K}$ and $10.0 \mathrm{MPa}$ ) was added to the vessel to achieve the desired mass ratio between reactants and $\mathrm{CO}_{2}$ (which ranged from 0.2 to 1.0 ). After that, the system was pressurized to 6.0 $\mathrm{MPa}$ and then to the desired reaction pressure condition (8.0 to $16.0 \mathrm{MPa}$ ) at a $0.5 \mathrm{MPa} \mathrm{min}^{-1}$ pressure rate, when the system was heated to the reaction temperature ( 45 to $65^{\circ} \mathrm{C}$ ). Geraniol to acetic acid molar ratio and biocatalyst concentration were kept constant at values chosen according to the results previously obtained using STR and the actual values are presented in Table S3 (SI section). As soon as the aimed pressure and temperature were attained, esterification was achieved according to the desired reaction time. Finally, prior to opening the reaction vessel, depressurization was performed using the same rate used for pressurization.

\section{Titration}

A titration method was employed to determine the reaction conversion when hexane was used as solvent. Ethanol $(10.0 \mathrm{~mL})$ was added to a screw-cap glass cup and its mass was measured. Then, approximately $200 \mathrm{mg}$ aliquots were withdrawn from the reaction media, added to the screw-cap glass cup, and the system was weighed again to provide the exact mass of the aliquot added to the solvent. Next, two drops of $1.0 \mathrm{wt} \%$ phenolphthalein in ethanol were added and the mixture was stirred using a C-MAG HS7 magnetic stirrer (IKA®, Staufen, Germany) to ensure system homogeneity and a proper mass transfer. After that, the titration was performed by adding an aqueous solution of sodium hydroxide $\left(0.01 \mathrm{~mol} \mathrm{~L}^{-1}\right)$, previously standardized with potassium hydrogen phthalate, using a digital Titrette ${ }^{\circledR}$ bottle-top burette (Brand, Wertheim, Germany). Since no side reactions were observed, as confirmed by gas chromatography (GC) analysis, it is possible to assume that acetic acid is converted only into geranyl acetate, and the conversion may be calculated using equation 1 :

$\mathrm{X}(\%)=100 \frac{\mathrm{AC}_{0}-\mathrm{AC}}{\mathrm{AC}_{0}}$

where $\mathrm{X}$ is the acetic acid conversion, and $\mathrm{AC}_{0}$ and $\mathrm{AC}$ are the acid contents present in the samples before and after the esterification, respectively, as obtained by titration.

\section{Gas chromatography}

The extent of conversion was analyzed using a GC-2010 Plus gas chromatograph (Shimadzu ${ }^{\circledR}$, Kyoto, Japan) coupled to a flame ion detector (GC-FID). The system was equipped with an autoinjector model AOC-20i and a Shimadzu SH-Rtx-Wax Crossbond ${ }^{\odot}$ Carbowax $^{\odot}$ polyethylene glycol capillary column $(30 \mathrm{~m} \times 0.32 \mathrm{~mm} ; 0.25 \mu \mathrm{m})$. The analytical methodology was adapted from a previous work of our research group. ${ }^{50}$ The injection volume was $1.0 \mu \mathrm{L}$ (split ratio of 1:20), with the injector and detector temperatures set to 230 and $240{ }^{\circ} \mathrm{C}$, respectively. The column oven operated initially at $130{ }^{\circ} \mathrm{C}$, which was further increased

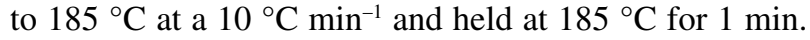
Helium 5.0 was used as the carrier gas at $1.75 \mathrm{~mL} \mathrm{~min}^{-1}$. Methyl laurate was used as internal standard and added to the samples as a solution in heptane $\left(8.4774 \mathrm{mg} \mathrm{mL}^{-1}\right)$. The amount of the internal standard solution was 200 and $35 \mu \mathrm{L}$, for samples of reactions performed using hexane and $\mathrm{CO}_{2}$, respectively. The quantification was performed using internal standard calibration curves ranging from 0.0061 to $0.1997 \mathrm{mg} \mathrm{mL}^{-1}$ for geraniol (coefficient of determination $\left.\left(\mathrm{R}^{2}\right)=0.9992\right)$ and 0.0064 to $0.2250 \mathrm{mg} \mathrm{mL}^{-1}$ for geranyl acetate $\left(R^{2}=0.9991\right)$.

Geraniol conversions were eventually calculated using a relationship similar to that presented in equation 1 , except that geraniol concentrations were used instead of acetic acid. It is also important to mention that all conversion values presented in this work are referred only to geraniol. This is possible because no side reactions were 

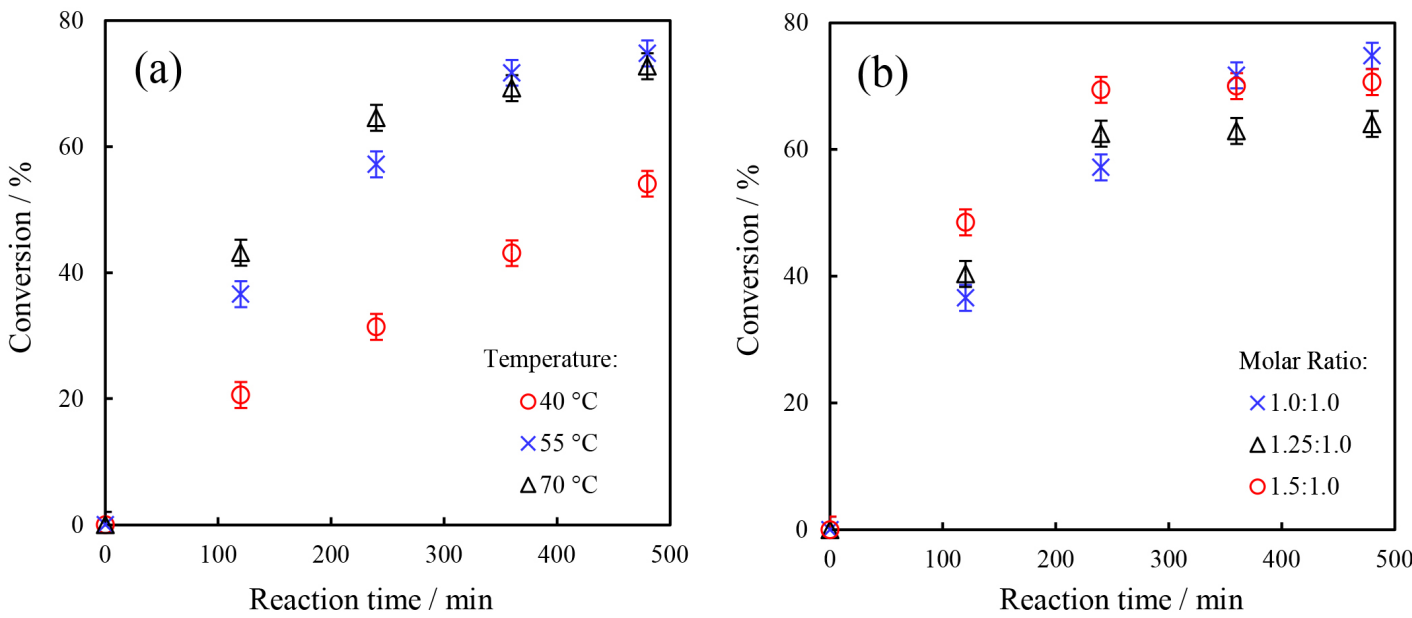

Figure 1. Experimental results of geranyl acetate synthesis from the esterification of geraniol using acetic acid, hexane and 20 wt.\% Lipozyme ${ }^{\circledR}$ RM $\mathrm{IM}$ in a stirred tank reactor (STR). Comparison of results obtained for (a) geraniol to acetic acid molar ratio of 1.0:1.0 at different temperatures, and (b) different molar ratios.

observed, as confirmed by GC analysis (please refer to the chromatograms shown in Figure S1, SI section). Thus, geraniol conversions can be considered identical to acetic acid conversions.

\section{Results and Discussion}

Geranyl acetate synthesis with acetic acid in hexane using Lipozyme ${ }^{\circledR}$ RM IM as biocatalyst

STR experiments with hexane were performed using three different temperatures $\left(40,55\right.$ and $\left.70{ }^{\circ} \mathrm{C}\right), 20 \mathrm{wt} . \%$ enzyme and a geraniol to acetic acid molar ratio of 1.0:1.0. Furthermore, at the central temperature of $55^{\circ} \mathrm{C}$, two other molar ratios were tested (1.25:1.0 and 1.5:1.0). The actual reaction conditions (temperature and pressure) and the amounts of reactants and hexane, as well as the times of reaction and the conversions obtained are presented in Table S2 (SI section) for every reaction performed with hexane as solvent. The two molar ratios were chosen so as to ensure that geraniol was present in a slight excess in the reaction system, since previous works ${ }^{16,46,51}$ have shown that short chain acids such as acetic acid act as an inactivation agent, possibly by acidifying the water layer surrounding the support, resulting in enzyme denaturation and the loss of its catalytic activity.

The results obtained for this set of experiments were compiled in Figure 1a, to show the temperature effect, and in Figures $1 \mathrm{~b}$ and 2, to evaluate the molar ratio effect. All results presented for STR experiments are shown as average values, with error bars of $\pm 2.05 \%$ that represent the expanded uncertainties with a $95 \%$ confidence level. This value was calculated by multiplying the resulting average experimental standard deviation by 4.30 ( $t$ for a probability of 0.05 with a degree of freedom of 2 , since each sample was analyzed in triplicates) and dividing by the square root of the number of samples. ${ }^{52}$

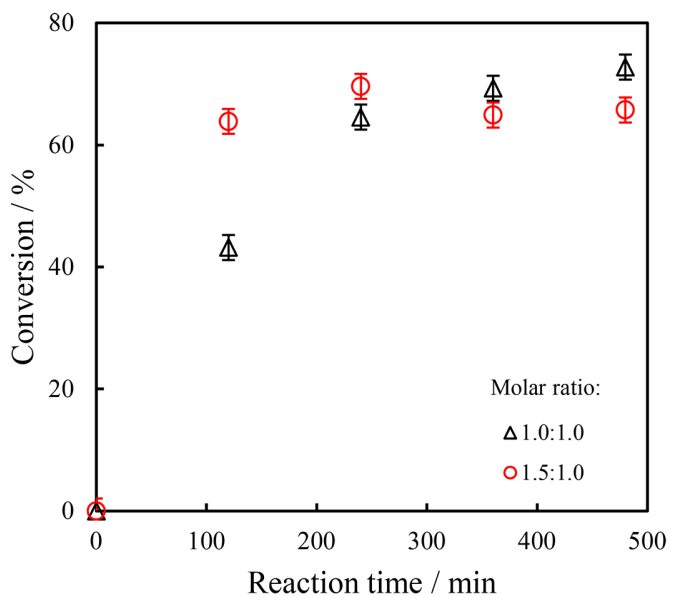

Figure 2. Experimental results of geranyl acetate synthesis from the esterification of geraniol using acetic acid, hexane and $20 \mathrm{wt} \%$ of Lipozyme ${ }^{\circledast}$ RM IM in a stirred tank reactor (STR). Comparison of results obtained at $70{ }^{\circ} \mathrm{C}$ for different molar ratios.

As can be seen in Figure 1a, for equimolar ratios of geraniol to acetic acid, and up to 240 min of reaction, molar conversions were correlated to the thermal energy provided to the system. When the reaction was carried out at $55^{\circ} \mathrm{C}$, conversion was closer to those obtained at $70{ }^{\circ} \mathrm{C}$, rather than to those obtained at $40{ }^{\circ} \mathrm{C}$. For longer reaction times, however, the exposure of the enzyme to a higher reaction temperature might have led to its thermal inactivation, explaining why, after $240 \mathrm{~min}$, conversion values were higher for the reaction performed at $55^{\circ} \mathrm{C}$ rather than at $70{ }^{\circ} \mathrm{C}$.

Furthermore, Figures $1 \mathrm{~b}$ and 2 show the effect of molar ratios at 55 and $70{ }^{\circ} \mathrm{C}$, respectively. At both temperatures, 
the reactions performed with excess of geraniol presented higher conversions for reaction times up to $240 \mathrm{~min}$. However, for further reaction times, the reactions performed with molar ratios of 1.25:1.0 and 1.5:1.0 presented lower conversions when compared to the equimolar reaction, indicating that the slight excess of geraniol may have been sufficient to cause inactivation of Lipozyme ${ }^{\circledR}$ RM IM.

A possible mechanism for this inactivation may be due to enzyme deactivation by hydrophobic interactions with the geraniol excess, which destabilizes the enzyme active sites and reduces its catalytic activity. ${ }^{44}$ This behavior was also observed by Chulalaksananukul et $a .^{7}$ and Claon and Akoh ${ }^{17}$ for Mucor miehei lipase (IM 20) and Mucor miehei lipases (IM 20 and IM 60), respectively, and Yee and Akoh ${ }^{18}$ for a nonspecific lipase from Pseudomonas sp. immobilized on glass beads. This distinct behavior should also be further studied in future works by scrutinizing the reaction chemical equilibrium through robust thermodynamic models.

Geranyl acetate synthesis with acetic acid in hexane using Novozym ${ }^{\circledR} 435$

Geranyl acetate synthesis was conducted with Novozym ${ }^{\circledR} 435$ in an STR with hexane at $55{ }^{\circ} \mathrm{C}$ using an equimolar ratio of geraniol and acetic acid to evaluate the biocatalyst performance. When comparing the results obtained with Lipozyme ${ }^{\circledR}$ RM IM and Novozym ${ }^{\circledR} 435$, the latter was clearly more attractive because it exhibited higher conversions at lower reaction times (Figure 3). After $240 \mathrm{~min}$, the conversion was $82.9 \%$ when Novozym ${ }^{\circledR} 435$ was used, while esterification using Lipozyme ${ }^{\circledR}$ RM IM took $480 \mathrm{~min}$ to achieve a $74.8 \%$ conversion.

The difference in the conversion using different lipases lies in intrinsic discrepancies between the enzymes.

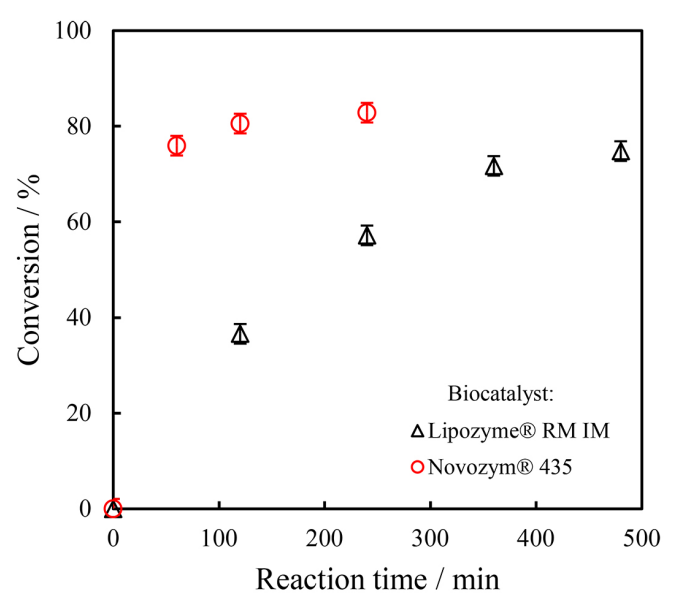

Figure 3. Geranyl acetate synthesis using acetic acid, hexane and $20 \mathrm{wt} \%$ biocatalyst in a stirred tank reactor (STR). Comparison of results obtained at $55^{\circ} \mathrm{C}$ with a molar ratio of 1.0:1.0 using different commercial lipases.
According to Nelson et al. ${ }^{53}$ lipases from Mucor miehei are more efficient for hydrolysis, while lipases from Candida antarctica are better for esterification and transesterification. Besides, the flapping lid of Lipozyme ${ }^{\circledR}$ RM IM protrudes into the binding pocket nearby, producing steric hindrance at the binding site by interfacial inactivation. ${ }^{44}$ On the other hand, the flapping lid is minimal in Novozym ${ }^{\circledR} 435$, generating less steric hindrance and leading to higher conversion rates..$^{8,44,54}$

Novozym ${ }^{\circledR} 435$ is composed of $C$. antarctica lipase B immobilized on an acrylic polymer resin named Lewatit VP OC 1600 by interfacial activation. ${ }^{54}$ This results in the proper orientation of the enzyme, maintaining its structural stability and providing a chemical environment that allows a favorable interaction with the substrate while retaining a small quantity of water in the matrix pores. ${ }^{44}$ According to the manufacturer, the Lewatit VP OC 1600 support is a macroporous matrix composed of poly(methyl methacrylate) crosslinked with divinylbenzene, forming spherical beads relatively hydrophobic. Some textural properties of such support are as follows: average particle size of 315-1000 $\mu \mathrm{m}$, average surface area of $130 \mathrm{~m}^{2} \mathrm{~g}^{-1}$ and average pore size of $150 \AA^{54}$

Since Novozym ${ }^{\circledR} 435$ presented higher activity compared to Lipozyme ${ }^{\circledR}$ RM IM, the enzyme concentration in relation to the reactants' quantity was reduced from 20 to $10 \mathrm{wt} . \%$ (Figure 4). Also, higher conversions were achieved in shorter reaction times (75.9\% after $60 \mathrm{~min}$ ) when $20 \mathrm{wt}$.\% enzyme was used. However, after $120 \mathrm{~min}$, both conditions resulted in similar conversions, reaching $83.7 \%$ after 240 min with 10 wt. $\%$ Novozym $^{\circledR} 435$, and $82.9 \%$ with 20 wt. $\%$ at the same reaction time. Therefore, aiming for a more economically attractive synthesis, further esterification reactions were conducted using $10 \mathrm{wt} \%$ enzyme.

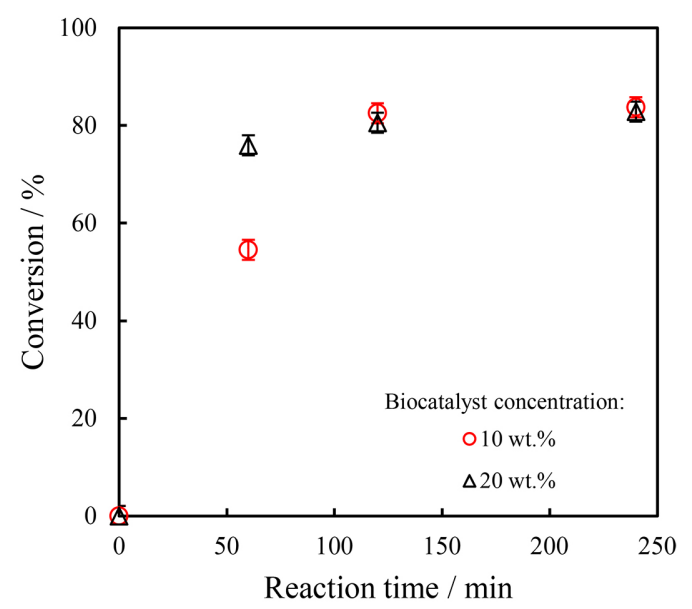

Figure 4. Experimental results of geranyl acetate synthesis using acetic acid and hexane in a stirred tank reactor (STR). Comparison of results obtained at $55^{\circ} \mathrm{C}$ and molar ratio of 1.0:1.0 for different Novozym ${ }^{\circledR} 435$ concentrations. 


\section{Geranyl acetate synthesis using supercritical $\mathrm{CO}_{2}\left(\mathrm{scCO}_{2}\right)$}

To replace the harmful hexane as the reaction solvent, $\mathrm{scCO}_{2}$ was employed due to its qualities and properties explained earlier. Preliminary experiments were carried out in an STR with a reactants molar ratio of $1.0: 1.0$ at $55^{\circ} \mathrm{C}$ and 10.0 MPa for $240 \mathrm{~min}$, using both biocatalytic systems. The esterification reaction $\mathrm{B} 1$ between geraniol and acetic acid using $20 \mathrm{wt}$.\% Lipozyme ${ }^{\circledR} \mathrm{RM}$ IM and $39.0 \mathrm{~g}$ of $\mathrm{scCO}_{2}$ did not show any conversion, while reaction $\mathrm{B} 2$, performed with 20 wt.\% Novozym ${ }^{\circledR} 435$ and $38.7 \mathrm{~g}$ of scCO${ }_{2}$, resulted in a $12.0 \%$ conversion. The actual reaction conditions (temperature and pressure) and amounts of reactants and $\mathrm{CO}_{2}$, as well as the reaction and conversions obtained are presented in Table S4 (SI section) for every reaction performed with $\mathrm{scCO}_{2}$ as solvent.

The difference observed between the two biocatalysts was also observed when hexane was used as the reaction solvent. Low conversion values were likely caused by the huge amount of $\mathrm{CO}_{2}$ that was required to achieve the desired reaction pressure (around $10 \mathrm{MPa}$ ), since in the STR system this parameter has a direct relationship with the amount of $\mathrm{CO}_{2}$ fed to the reaction system. Even though the role of $\mathrm{CO}_{2}$ in enzyme-catalyzed esterification is not entirely known, high $\mathrm{CO}_{2}$ loadings may lead to the dilution of both catalysts and reactants, decreasing the catalytic conversion. ${ }^{55}$

To thoroughly investigate the effects of both pressure and $\mathrm{CO}_{2}$ amount on the reaction performance, another experimental apparatus was required. Hence, another set of experiments using $\mathrm{scCO}_{2}$ was carried out in a variablevolume reactor (VVR) following a $2^{3}$ experimental design with three replicates at the central point (Table 1). The three evaluated reaction parameters were temperature, pressure, and reactants to $\mathrm{CO}_{2}$ mass ratio, with Novozym ${ }^{\circledR} 435$ used as catalyst due to the already observed low conversions provided by Lipozyme ${ }^{\circledR}$ RM IM. Agitation and reactants molar ratio were kept constant at $600 \mathrm{rpm}$ and 1.0:1.0, respectively, and the reaction was set at $60 \mathrm{~min}$ for all runs.
Table 1. Experimental design of reactions for the esterification of geraniol using acetic acid and $\mathrm{scCO}_{2}$ in a variable volume reactor (VVR), using a 1.0:1.0 molar ratio and $60 \mathrm{~min}$ as the reaction time. Responses are given in terms of geraniol conversion

\begin{tabular}{lcccc}
\hline Run & $\begin{array}{c}\text { Temperature / } \\
{ }^{\circ} \mathrm{C}\end{array}$ & $\begin{array}{c}\text { Pressure / } \\
\mathrm{MPa}\end{array}$ & $\begin{array}{c}\text { Reactants to } \\
\mathrm{CO}_{2} \text { mass ratio }\end{array}$ & $\begin{array}{c}\text { Conversion / } \\
\%\end{array}$ \\
\hline P1 & 45 & 8.0 & 0.2 & 25.8 \\
P2 & 65 & 8.0 & 0.2 & 43.1 \\
P3 & 45 & 16.0 & 0.2 & 30.9 \\
P4 & 65 & 16.0 & 0.2 & 46.9 \\
P5 & 45 & 8.0 & 1.0 & 19.9 \\
P6 & 65 & 8.0 & 1.0 & 44.4 \\
P7 & 45 & 16.0 & 1.0 & 24.1 \\
P8 & 65 & 16.0 & 1.0 & 45.4 \\
P9 & 55 & 12.0 & 0.6 & 29.2 \\
P10 & 55 & 12.0 & 0.6 & 29.4 \\
P11 & 55 & 12.0 & 0.6 & 31.1 \\
\hline
\end{tabular}

The reaction system was observed through the frontal window of the VVR to ensure the presence of a single liquid-phase (composed by reactants and solvent) in contact with the solid biocatalyst. Such characteristic of the reaction medium could facilitate the mass transport of the reactants, from the bulk of reaction to the catalyst surface and then to internal pores. During a screening experiment, the system was pressurized at $10.0 \mathrm{MPa}$ and, at first, the reaction media indeed presented a single liquid-phase. However, after $60 \mathrm{~min}$, a two-phase (liquid-liquid) system was formed due to water and ester formation. Thus, the pressure was increased to $12.0 \mathrm{MPa}$ and this new value was used at the central point of the experimental design. In addition, when the pressure was 8.0 $\mathrm{MPa}$, there was a vapor-liquid-solid system, as observed in Figure 5a, while at both 12.0 and 16.0 $\mathrm{MPa}$ (Figures 5b and 5c, respectively), the reaction system presented the desired phase behavior.

A comparison with literature data indicated that the conversions obtained in this work were higher than those

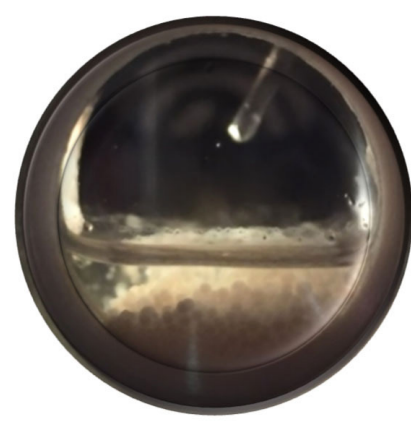

(a)

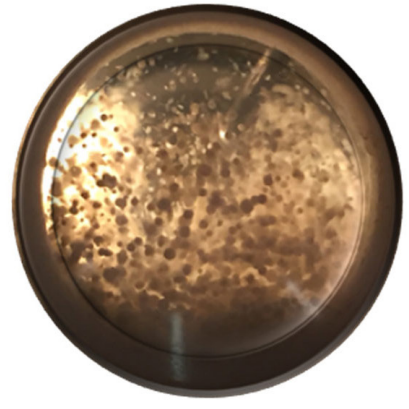

(b)

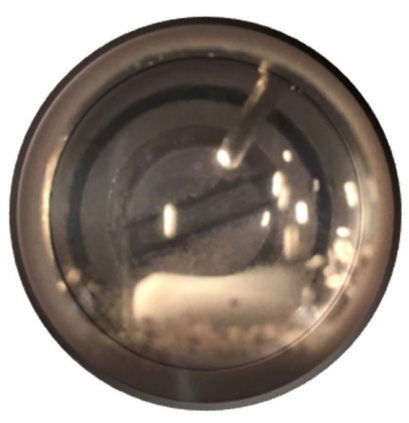

(c)

Figure 5. Inside view of the variable volume reactor (VVR) during geranyl acetate synthesis using acetic acid and $\mathrm{scCO}_{2}$ : (a) vapor-liquid-solid reaction system at $8.0 \mathrm{MPa}$ (agitation off); (b) liquid-solid mixture at 12.0 MPa (agitation on); and (c) liquid-solid mixture at 16.0 MPa (agitation off). 
obtained in studies performed either in VVR (less than 25\% after $60 \mathrm{~min}$ ) by Peres et al., ${ }^{27}$ and STR (less than $20 \%$ after $60 \mathrm{~min}$ ), by Couto et al. ${ }^{26}$ Compared to Peres et al..${ }^{27}$ the main difference of the experimental procedure is that in our work the pressure was not related to the amount of $\mathrm{CO}_{2}$ added to the system.

The conversion results presented in Table 1 were statistically evaluated by analysis of variance (ANOVA), performed using the software Statistica ${ }^{\circledR}$, version 13.5.0 (TIBCO, Palo Alto, USA), ${ }^{56}$ to measure the main effects of the process variables. Thus, within the ranges tested in this work, only temperature was statistically relevant to reaction conversion according to the Pareto chart presented in Figure 6.

A rigorous evaluation of the data indicated that at lower temperatures $\left(45\right.$ and $\left.55^{\circ} \mathrm{C}\right)$ the conversion values were more susceptible to changes in both pressure and the amount of $\mathrm{CO}_{2}$, as shown in Figure S2a (SI section). For the same amounts of $\mathrm{CO}_{2}$ (or equal reactants to $\mathrm{CO}_{2}$ mass ratios), higher pressures resulted in higher conversions. For an increase in the pressure from 8 to $16 \mathrm{MPa}$ when the mass ratio was 0.2 , the conversion increased from 25.8 to $30.9 \%$, while when the mass ratio was 1.0 , the conversion increased from 19.9 to $24.1 \%$. Moreover, considering once again the reactions performed at $45^{\circ} \mathrm{C}$, the amount of $\mathrm{CO}_{2}$ influenced reaction conversion when pressure was kept constant in the system. In this sense, at $8 \mathrm{MPa}$, a decrease in the reactants to $\mathrm{CO}_{2}$ mass ratio from 1.0 to 0.2 led to an increase in conversion from 19.9 to $25.8 \%$, respectively, while at $16 \mathrm{MPa}$, the conversion increased from 24.1 to $30.9 \%$.

The effects of both pressure and amount of $\mathrm{CO}_{2}$ were indeed small for the reactions performed at $65^{\circ} \mathrm{C}$, regardless the applied pressure and mass ratio, if these parameters were in the range of 8.0 to $16.0 \mathrm{MPa}$ and 0.2 to 1.0 , respectively. The observed conversions, between 43.1 and $46.9 \%$, lied within analytical uncertainty and slight differences in reaction times, which accounted periods of heating, pressurization, depressurization, and cooling. A further attempt was performed in order to verify whether a lesser amount of $\mathrm{CO}_{2}$ could be meaningful to the geraniol conversion at this temperature. For this, reaction $\mathrm{P} 12$ was performed in the VVR at $65{ }^{\circ} \mathrm{C}$ and $16.0 \mathrm{MPa}$ using $3.4 \mathrm{~g} \mathrm{CO}_{2}$ (mass ratio of reactants to $\mathrm{CO}_{2}$ around 2.0 ), and provided a geraniol conversion of $48.5 \%$ after $60 \mathrm{~min}$. The comparison between this result and those obtained in the same reactor and at the same temperature indicated that the use of less $\mathrm{CO}_{2}$ could enhance geraniol conversion as presented in Figure S2b (Supplementary Information). However, this result is arguable considering the uncertainties involved in these experiments.

Some of the conditions presented in Table 1 were further studied for other reaction times to evaluate the effects of both pressure and $\mathrm{CO}_{2}$ amount on reaction conversion. Reactions were performed using conditions of the central point (P9 to P11) and of reactions $\mathrm{P} 4$ (in which higher conversions were obtained) and P8 (to evaluate the effect of $\mathrm{CO}_{2}$ amount). The results indicated that when a higher amount of $\mathrm{CO}_{2}$ was employed, a higher conversion was obtained only for a reaction time of $30 \mathrm{~min}$ (Figure 7). However, after this reaction time, every other conversion values were nearly identical. Furthermore, until $120 \mathrm{~min}$, conversion values were lower for reactions performed at $55{ }^{\circ} \mathrm{C}$, but after $240 \mathrm{~min}$, this reaction presented similar conversions to those obtained at $65{ }^{\circ} \mathrm{C}$. The results presented in Figure 7, representing average values for geraniol conversion, and error bars of $\pm 3.21 \%$ represent the expanded uncertainties with a $95 \%$ confidence level. This value was calculated by multiplying the average experimental standard deviation by 4.30 and dividing it by the square root of the number of samples $(t$ for a probability of 0.05 and degree of freedom equal to 2 for analyses carried out in triplicates).$^{52}$

It is also necessary to consider the reasons for the success or failure of a solvent for a given enzyme-catalyzed reaction. Laane et al. ${ }^{57}$ tried to establish a correlation

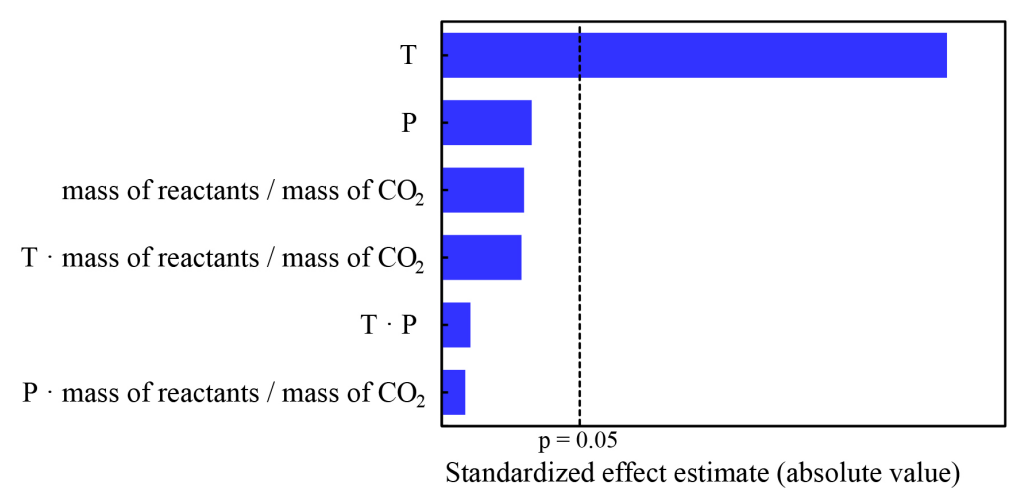

Figure 6. Pareto chart of standardized effect for reactions performed in a variable volume reactor (VVR) following the experimental design, with responses given in terms of geraniol conversion. 


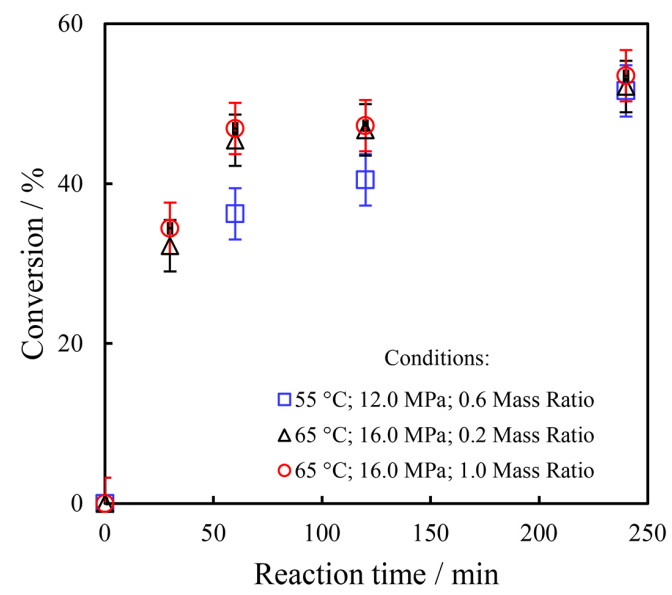

Figure 7. Experimental results of geranyl acetate synthesis using acetic acid and $\mathrm{scCO}_{2}$ at $65{ }^{\circ} \mathrm{C}$, with a molar ratio of 1.0:1.0 and $20 \mathrm{wt} . \%$ Novozym $^{\circledR} 435$ in a variable volume reactor (VVR).

between enzyme activity and solvent polarity (presented as $\log$ P). Later, Narayan and Klibanov ${ }^{58}$ observed that the flexibility of an enzyme is affected by the dielectric constant $\varepsilon$ (or relative permittivity) of the solvents. Thus, as the enzyme becomes more flexible in solvents with high $\varepsilon$, it may undergo denaturation and have its activity decreased. ${ }^{58}$ As already mentioned, density-dependent properties of carbon dioxide such as relative permittivity can be tuned through appropriate changes in temperature and pressure. The values of this property according to the reaction conditions are presented in Table S5 (Supplementary Information) and were based on experimental data available in literature. ${ }^{59,60}$ The uniqueness of carbon dioxide is also verified by its partial affinity with polar molecules at supercritical conditions, which is due to its large molecular quadrupole moment, despite being a linear molecule with no dipole moment. ${ }^{61}$

The understanding of the role of $\mathrm{CO}_{2}$ in such reaction systems must be evaluated at the molecular level. Matsuda $^{38}$ performed computer simulations to determine the molecular aspects of Novozym ${ }^{\circledR} 435$ stability and found that water and $\mathrm{scCO}_{2}$ are likely to cover the protein surface heterogeneously, according to their affinity to hydrophilic or hydrophobic surface amino acid residues. Therefore, polar solvents withdraw water from the surface of the enzyme and eventually transport these molecules to the reaction bulk. Since a certain amount of water is required for the micro-layer surrounding the enzyme in order to maintain its conformational flexibility, enzyme dehydration is one of the main causes for its deactivation. ${ }^{10,13}$ On the other hand, by exceeding the critical amount of water required for the proper enzyme functioning, the thickness of the water layer around the enzyme is increased, leading to an additional gain in enzyme flexibility that may also be a cause for its denaturation. ${ }^{14}$
These considerations are important for reactions that are subject of this study because water is formed as a by-product. If the solvent has no affinity with water, the enzyme surface can be entirely hydrated, resulting in loss of enzyme activity. Peres et al. ${ }^{27}$ observed that, for reactions carried out with scEthane, the enzyme was visibly hydrated due to a lower affinity of this solvent with water, as compared to $\mathrm{scCO}_{2}$ (despite the use of scEthane resulted in higher conversions). Moreover, the presence of an undesirable amount of water reversed the reaction equilibrium toward ester hydrolysis, leading to a decrease in the esterification rate. ${ }^{5}$ For this reason, it is important to remove water or control its presence by adding salts, ${ }^{27}$ molecular sieves, ${ }^{6,14-16,26}$ or desiccants ${ }^{24}$ to the reaction media, using pervaporation membranes ${ }^{40}$ or performing the reaction under vacuum. ${ }^{27}$

Therefore, an additional experiment was performed in the STR due to its considerable headspace volume, which allows the formation of a larger vapor phase. Reaction B3 was performed at $55{ }^{\circ} \mathrm{C}$ using a reactants molar ratio of 1.0:1.0, 10 wt.\% Novozym ${ }^{\circledast} 435$ and $19.6 \mathrm{~g} \mathrm{CO}_{2}$, which corresponds to a mass ratio of reactants to $\mathrm{CO}_{2}$ of 0.6 . The STR system presented two phases, liquid and vapor, and the pressure corresponded to the vapor pressure of the reaction mixture. Under these conditions, the STR inner pressure reached $6.4 \mathrm{MPa}$, and $\mathrm{CO}_{2}$ was partially dissolved in the reaction media, causing its expansion, and improving its transport properties. At the same time, it was expected that the affinity between water and $\mathrm{CO}_{2}$ would be enough for $\mathrm{CO}_{2}$ to drag the formed water molecules to the bulk of reaction media and then to the vapor phase. The conversion after $240 \mathrm{~min}$ was $60.5 \%$, which is much higher than the $12.0 \%$ conversion obtained using $38.7 \mathrm{~g} \mathrm{scCO}_{2}$.

Although worse than those obtained when hexane was used as solvent, such conversion was the highest conversion for reactions carried out in the presence of $\mathrm{CO}_{2}$, being useful to support the use of $\mathrm{CO}_{2}$-expanded liquids in further studies related to enzyme-catalyzed reaction systems. Some aspects which were not evaluated in this work still deserve attention when dealing with optimization of such reaction systems. The reusability of the biocatalyst must be carefully evaluated when using pressurized $\mathrm{CO}_{2}$ because pressurization/depressurization cycles may cause structural damage and reduce its longevity. The stirring speed is also highly influential to meet the transport properties needed for high product yields. Finally, the water content is of outmost importance, particularly for reactions that release water as by-product (and so its presence has a negative effect over the molar conversions), since a certain amount of water is required for the enzyme to keep its biological functionality. 


\section{Conclusions}

This work reported the state-of-art of geranyl acetate synthesis and presented experimental data for reactions involving geraniol, acetic acid, lipases (Lipozyme ${ }^{\circledR}$ RM IM and Novozym ${ }^{\circledR} 435$ ) and solvents (hexane and $\mathrm{scCO}_{2}$ ) in two batch-type reactors (STR and VVR). Novozym ${ }^{\circledR} 435$ took nearly half the time to achieve similar reaction conversions compared to Lipozyme ${ }^{\circledR}$ RM IM. Regarding the effect of solvents, the use of hexane yields much higher geraniol conversions when compared to $\mathrm{CO}_{2}$, at the same temperature and for the same reaction times. The use of VVR was helpful to provide an insight on the phase behavior of the reaction mixture containing $\mathrm{CO}_{2}$ and along the reaction course, for different amounts of $\mathrm{CO}_{2}$ and conditions of temperature and pressure.

The results obtained suggested that $\mathrm{CO}_{2}$ might help removing the formed water from the supported enzyme, as well as enhancing transport properties due to expansion of the reaction media. Thus, using a STR and the proper conditions of temperature and pressure, it was possible to obtain a considerable increase in the geraniol conversion. While still lower than the geraniol conversions obtained using hexane, the use of $\mathrm{CO}_{2}$ is interesting from a process intensification standpoint and also considering solvent toxicity. Moreover, this work is one step forward to a clear understanding of the role of $\mathrm{CO}_{2}$ in enzyme-catalyzed reactions, aiming at improvements in reaction performance while using a safer and greener solvent compared to hexane.

\section{Supplementary Information}

Supplementary information (chromatograms, reaction conditions and conversion results obtained in this work, thermodynamic properties, and a summary of related works available in literature) is available free of charge at http://jbcs.sbq.org.br as PDF file.

\section{Acknowledgments}

The authors are thankful to the Brazilian funding agencies CNPq (grants 305393/2016-2, 309506/2017-4, and 435873/2018-0), CAPES (Finance Code 001) and Fundação Araucária (grant 004/2019) for the financial support to carry out this study.

\section{Author Contributions}

Matheus V. L. Tavares was responsible for the methodology, investigation, formal analysis, writing - original draft; Luís R. S. Kanda for the conceptualization, methodology, writing - review and editing; Wanderson R. Giacomin Júnior for the methodology, investigation, writing - review and editing; Luiz P. Ramos for the supervision, writing - review and editing; Luciana P. S. Vandenberghe for the supervision, writing - review and editing; Marcos L. Corazza for the conceptualization, resources, supervision, writing - review and editing, funding acquisition.

\section{References}

1. Wan, L.; Li, H.; Huang, C.; Feng, Y.; Chu, G.; Zheng, Y.; Tan, W.; Qin, Y.; Sun, D.; Fang, Y.; J. Chem. Thermodyn. 2017, 109, 109.

2. Li, H.; Zhang, T.; Fu, W.; Tamura, K.; J. Chem. Eng. Data 2012, 57,148 .

3. Xiong, J.; Huang, Y.; Zhang, H.; Hou, L.; Food Sci. Technol. Res. 2014, 20, 207.

4. Murcia, M. D.; Gómez, M.; Gómez, E.; Gómez, J. L.; Hidalgo, A. M.; Sánchez, A.; Vergara, P.; Chem. Eng. Res. Des. 2018, $138,135$.

5. Karra-Chaabouni, M.; Pulvin, S.; Touraud, D.; Thomas, D.; Biotechnol. Lett. 1996, 18, 1083.

6. Molinari, F.; Villa, R.; Aragozzini, F.; Biotechnol. Lett. 1998, $20,41$.

7. Chulalaksananukul, W.; Condoret, J. S.; Combes, D.; Enzyme Microb. Technol. 1992, 14, 293.

8. Shinde, S. D.; Yadav, G. D.; Appl. Biochem. Biotechnol. 2015, 175, 2035.

9. Gupta, A.; Dhakate, S. R.; Pahwa, M.; Sinha, S.; Chand, S.; Mathur, R. B.; Process Biochem. 2013, 48, 124.

10. Badgujar, K. C.; Bhanage, B. M.; Process Biochem. 2014, 49 , 1304.

11. Shieh, C. J.; Akoh, C. C.; Yee, L. N.; Biotechnol. Bioeng. 1996, 51,371 .

12. Bartling, K.; Thompson, J. U. S.; Pfromm, P. H.; Czermak, P.; Rezac, M. E.; Biotechnol. Bioeng. 2001, 75, 676.

13. Bezbradica, D.; Mijin, D.; Šiler-Marinković, S.; Knežević, Z.; J. Mol. Catal. B: Enzym. 2007, 45, 97.

14. Damnjanović, J. J.; Žuža, M. G.; Savanović, J. K.; Bezbradica, D. I.; Mijin, D. Ž.; Bošković-Vragolović, N.; Knežević-Jugović, Z. D.; J. Mol. Catal. B: Enzym. 2012, 75, 50.

15. Knežević-Jugović, Z. D.; Damnjanović, J. J.; Bezbradica, D. I.; Mijin, D. Ž.; Chem. Ind. Chem. Eng. Q. 2008, 14, 245.

16. Claon, P. A.; Akoh, C. C.; Biotechnol. Lett. 1993, 15, 1211.

17. Claon, P. A.; Akoh, C. C.; J. Am. Oil Chem. Soc. 1994, 71, 575.

18. Yee, L. N.; Akoh, C. C.; JAOCS, J. Am. Oil Chem. Soc. 1996, $73,1379$.

19. Rosa, B. H.; Silva, G. S.; Conceição, G. J. A.; Carvalho, R. A.; Aguiar-Oliveira, E.; Maldonado, R. R.; Kamimura, E. S.; Biocatal. Agric. Biotechnol. 2017, 12, 90.

20. Chen, J. P.; Lin, W. S.; Chang, M. F.; JAOCS, J. Am. Oil Chem. Soc. 2002, 79, 309. 
21. Pellis, A.; Cantone, S.; Ebert, C.; Gardossi, L.; New Biotechnol. 2018, 40, 154

22. Zaks, A.; Klibanov, A. M.; Proc. Natl. Acad. Sci. 1985, 82, 3192.

23. Sing, S.; Pandey, A.; Singhania, R. S.; Larroche, C.; Li, Z.; Biomass, Biofuels, Biochemicals: Advances in Enzyme Catalysis and Technologies, $1^{\text {st }}$ ed.; Singh, S. P.; Pandey, A.; Singhania, R. R.; Larroche, C.; Li, Z., eds.; Elsevier B.V.: Amsterdam, 2020.

24. Bourkaib, M. C.; Randriamalala, H.; Dettori, L.; Humeau, C.; Delaunay, S.; Chevalot, I.; Guiavarc'h, Y.; Process Biochem. 2018, 71, 118.

25. Martins, A. B.; da Silva, A. M.; Schein, M. F.; Garcia-Galan, C.; Ayub, M. A. Z.; Fernandez-Lafuente, R.; Rodrigues, R. C.; J. Mol. Catal. B: Enzym. 2014, 105, 18.

26. Couto, R.; Vidinha, P.; Peres, C.; Ribeiro, A. S.; Ferreira, O.; Oliveira, M. V.; Macedo, E. A.; Loureiro, J. M.; Barreiros, S.; Ind. Eng. Chem. Res. 2011, 50, 1938.

27. Peres, C.; da Silva, M. D. R. G.; Barreiros, S.; J. Agric. Food Chem. 2003, 51, 1884.

28. Varma, M. N.; Madras, G.; J. Chem. Technol. Biotechnol. 2008 83,1135 .

29. Marty, A.; Chulalaksananukul, W.; Willemot, R. M.; Condoret, J. S.; Biotechnol. Bioeng. 1992, 39, 273.

30. Escorsim, A. M.; Cordeiro, C. S.; Ramos, L. P.; Ndiaye, P. M.; Kanda, L. R. S.; Corazza, M. L.; J. Supercrit. Fluids 2015, 96, 68.

31. Veiga, B. A.; dos Santos, J. T. F.; Luz Junior, L. F. L.; Corazza, M. L.; J. Chem. Thermodyn. 2017, 112, 240.

32. Kumar, R.; Madras, G.; Modak, J.; Ind. Eng. Chem. Res. 2004, 43,1568 .

33. Romero, M. D.; Calvo, L.; Alba, C.; Habulin, M.; Primožič, M.; Knez, Ž.; J. Supercrit. Fluids 2005, 33, 77.

34. dos Santos, P.; Meireles, M. A. A.; Martínez, J.; J. Supercrit. Fluids 2017, 127, 71.

35. Daza Serna, L. V.; Orrego Alzate, C. E.; Cardona Alzate, C. A.; Bioresour. Technol. 2016, 199, 113.

36. Chulalaksananukul, W.; Condoret, J. S.; Combes, D.; Enzyme Microb. Technol. 1993, 15, 691.

37. Varma, M. N.; Madras, G.; Appl. Biochem. Biotechnol. 2010 , 160,2342

38. Matsuda, T.; J. Biosci. Bioeng. 2013, 115, 233.

39. Ferraz, L. I. R.; Possebom, G.; Alvez, E. V.; Cansian, R. L.; Paroul, N.; de Oliveira, D.; Treichel, H.; Biocatal. Agric. Biotechnol. 2015, 4, 44.

40. Chatterjee, T.; Bhattacharyya, D. K.; Biotechnol. Lett. 1998, 20, 865 .

41. Paroul, N.; Grzegozeski, L. P.; Chiaradia, V.; Treichel, H.; Cansian, R. L.; Oliveira, J. V.; de Oliveira, D.; J. Chem. Technol. Biotechnol. 2010, 85, 1636.
42. Isah, A. A.; Mahat, N. A.; Jamalis, J.; Attan, N.; Zakaria, I. I.; Huyop, F.; Wahab, R. A.; Prep. Biochem. Biotechnol. 2017, 47, 199.

43. Wang, L.; Chen, G.; Tang, J.; Ming, M.; Jia, C.; Feng, B.; Food Biosci. 2019, 27, 60.

44. Salvi, H. M.; Kamble, M. P.; Yadav, G. D.; Appl. Biochem. Biotechnol. 2018, 184, 630.

45. Tang, J.; Chen, G.; Wang, L.; Miao, M.; Jiang, B.; Feng, B.; J. Mol. Catal. B: Enzym. 2016, 133, S311.

46. Huang, S. Y.; Chang, H. L.; J. Chem. Technol. Biotechnol. 1999, $74,183$.

47. Pinto, L. F.; da Silva, D. I. S.; da Silva, F. R.; Ramos, L. P.; Ndiaye, P. M.; Corazza, M. L.; J. Chem. Thermodyn. 2012, 44, 57.

48. Giacomin Junior, W. R.; Capeletto, C. A.; Voll, F. A. P.; Corazza, M. L.; J. Chem. Eng. Data 2019, 64, 2011.

49. Tavares, M. V. L.; Giacomin-Junior, W. R.; Vandenberghe, L. P. D. S.; Chapman, W. G.; Corazza, M. L.; J. Chem. Eng. Data 2020, 65, 1721.

50. da Silva Junior, V. A.; Kanda, L. R. S.; Zandoná-Filho, A.; Corazza, M. L.; de Lima, C. S.; J. CO2 Util. 2020, 39, 101158.

51. Yadav, G. D.; Lathi, P. S.; J. Mol. Catal. B: Enzym. 2004, 27, 113.

52. Heckert, N. A.; Filliben, J. J.; Croarkin, C. M.; Hembree, B.; Guthrie, W. F.; Tobias, T.; Prinz, J.; Handbook 151: NIST/ SEMATECH e-Handbook of Statistical Methods; available at https://www.itl.nist.gov/div898/handbook/mpc/mpc.htm, accessed in December 2021.

53. Nelson, L. A.; Foglia, T. A.; Marmer, W. N.; JAOCS, J. Am. Oil Chem. Soc. 1996, 73, 1191

54. Ortiz, C.; Ferreira, M. L.; Barbosa, O.; dos Santos, J. C. S.; Rodrigues, R. C.; Berenguer-Murcia, Á.; Briand, L. E.; Fernandez-Lafuente, R.; Catal. Sci. Technol. 2019, 9, 2380.

55. Melfi, D. T.; dos Santos, K. C.; Ramos, L. P.; Corazza, M. L.; J. Supercrit. Fluids 2020, 158, 104736.

56. StatSoft; Statistica, 13.5.0; TIBCO Software, USA, 2018.

57. Laane, C.; Boeren, S.; Vos, K.; Veeger, C.; Biotechnol. Bioeng. 1987, 30, 81

58. Narayan, V. S.; Klibanov, A. M.; Biotechnol. Bioeng. 1993, 41, 390.

59. Michels, A.; Michels, C.; Philos. Trans. R. Soc., A 1933, 231, 409.

60. Keyes, F. G.; Kirkwood, J. G.; Phys. Rev. 1930, 36, 754.

61. Manjare, S. D.; Dhingra, K.; Mater. Sci. Energy Technol. 2019, $2,463$.

Submitted: September 27, 2021 Published online: January 11, 2022 